\title{
OLGA ANTOWSKA-GORACZZNIAK
}

\section{Wezesnogotycka katedra w Poznaniu}

\section{The Early Gothic cathedral in Poznań}

Zarys treści: Artykuł prezentuje stan rozpoznania archeologicznego katedry poznańskiej w odniesieniu do wczesnogotyckiej przebudowy chóru i kolejnych inwestycji budowlanych sprzed połowy XIV wieku.

Słowa kluczowe: wczesny gotyk; katedra; warsztat budowlany; pochówki.

Badania archeologiczne prowadzone po II wojnie światowej we wnętrzu katedry na Ostrowie Tumskim w Poznaniu odsłoniły kolejne fazy przebudowy obiektu: przedromańską, romańską, wczesnogotycką i gotycką. Ze względu na śladowość zachowania wczesnogotyckich reliktów architektonicznych największą dyskusję budzi właśnie XIII-wieczna przebudowa elementów konstrukcyjno-dekoracyjnych (ryc. 1). Rozważań nad tym problemem z pewnością nie ułatwia fakt, że większość istotnych prac pod katedrą była prowadzona przez historyków sztuki, którzy w niewielkim stopniu (przede wszystkim dla najstarszych faz) respektowali metodykę badań archeologicznych. Jedynie pierwsze prace wykopaliskowe prowadzone w 1946 roku przez Witolda Hensla (z ramienia Instytutu Prehistorycznego Uniwersytetu Poznańskiego) pozwoliły na szczegółowe, archeologiczne rozpoznanie stratygrafii w obrębie chóru oraz w dwóch sondażach założonych w nawach bocznych, na wysokości filarów tęczy (Przewoźna 1959) - właśnie te stanowią podstawę opracowań wyników badań z lat 1951-1956, prowadzonych przez Zdzisława Kępińskiego i Krystynę Józefowiczównę w ramach programu badań milenijnych ${ }^{1}$ (Józefowiczówna 1963). Podczas wspomnianych prac skupiono się przede wszystkim na udokumentowaniu i rozpoznaniu reliktów architektonicznych. Natomiast materiały archeologiczne $\mathrm{z}$ warstw często nie były zbierane, co

\footnotetext{
${ }^{1}$ Kierownictwo Badań nad Początkami Państwa Polskiego, Stacja Archeologiczna Poznań-Katedra.
} 

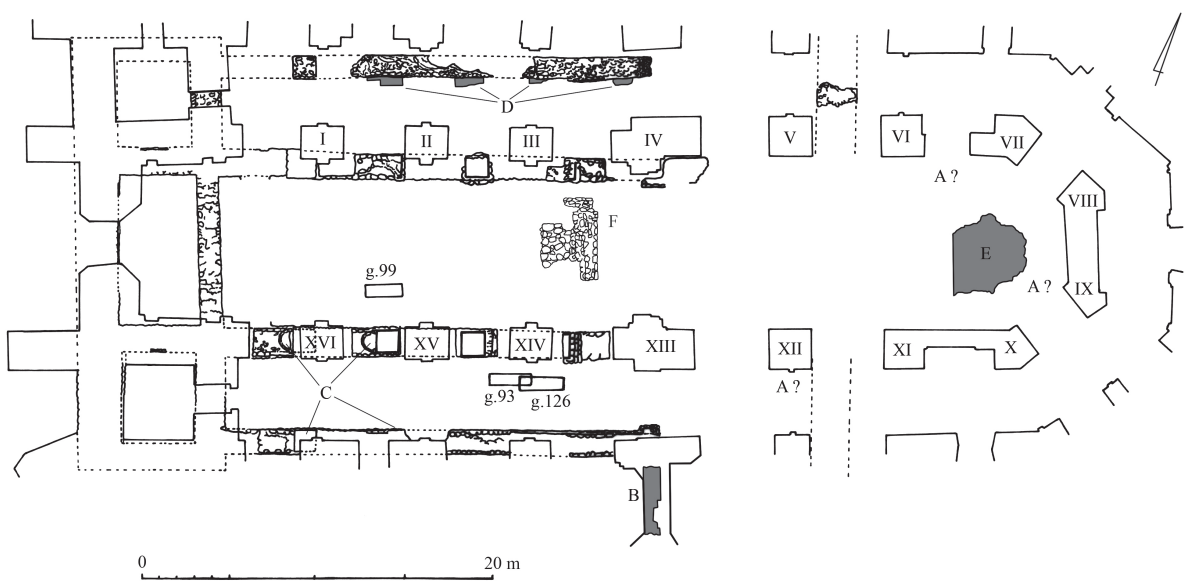

Ryc. 1. Poznań, Ostrów Tumski. Zarys korpusu romańskiego katedry i reliktów wczesnogotyckich z badań w latach 1951-1956. A - chór, domniemane fundamenty z połowy XIII wieku; B - ceglana ściana transeptu z późnoromańskim oknem; $\mathrm{C}$ - relikty półkolumn, filaru i fragmentu zamknięcia ściany tzw. kaplicy królewskiej Przemysła II i Ryksy; D - ceglane ,plinty” dostawione do północnej obwodowej ściany romańskiej; E - relikty ołtarza głównego; F - relikty ołtarza św. Trójcy(?); g - groby nr 93, 99, 126 (wg Józefowiczówna 1963 z uzupełnieniami autorki)

Fig. 1. Poznań, Ostrów Tumski. The outline of the edifice of the Romanesque cathedral and of early Gothic remains from research in 1951-1956. A - choir, the suspected foundation from the mid- $13^{\text {th }}$ century; $\mathrm{B}$ - brick transept wall with late Romanesque window; $\mathrm{C}$ - remains of engaged columns, pillars and wall closing fragment of the so-called royal chapel of Przemysł II and Ryksa; D - brick 'plinths' attached to the northern Romanesque perimeter wall; $\mathrm{E}$ - remains of the main altar; F - remains of St Trinity's (?) altar; G - graves Nos. 93, 99 and 126 (after Józefowiczówna 1963 with the author's additions)

tłumaczono tempem wykonywanego równolegle remontu katedry; nie rozdzielano ich także w obrębie warstwy zinterpretowanej jako wczesnogotycka i gotycka (warstwa II). Badania z lat 1951-1956 - pomimo archeologicznych niedopatrzeń - są istotne ze względu na wydzielenie następnych faz budowlanych obiektu.

Kolejne nadzory - w latach 1974 i 1997 - wykonywane przy udziale archeologów we wnętrzu katedry (badania ratownicze i towarzyszące pracom konserwatorskim) nie miały dla omawianego problemu większego znaczenia (Informator 1975, s. 192-193; Kaczmarek 2008, s. 192). Brakuje natomiast dokumentacji i materiałów archeologicznych z prac związanych z osuszaniem i izolacją fundamentów oraz ścian katedry w latach 1988, 1999 i 2000; doszło do odsłonięcia w kilku miejscach fragmentów przemurowań w wątku wendyjskim (Linette 1988, s. 100; Gałka 2001, s. 43, przypis 126). 
Niestety, nie wszystkie wymienione w literaturze relikty z archeologicznego, architektonicznego i konserwatorskiego punktu widzenia dostępne są do weryfikacji (dokumentacja nie została oddana do odpowiednich służb lub została zagubiona). W przypadku niektórych pozostaje tylko wiara $\mathrm{w}$ ich istnienie na podstawie opisów zamieszczonych przez autorów publikacji, niepopartych żadną dokumentacją (ryciny, fotografie). Wykonana na potrzeby artykułu kwerenda archiwaliów w Biurze Miejskiego Konserwatora Zabytków w Poznaniu i Archiwum Muzeum Archeologicznego w Poznaniu nie dała odpowiedzi na wiele pytań i wątpliwości dotyczących przebudowy katedry w XIII wieku. W związku z powyższym do dzisiaj trwa dyskusja i są podzielone zdania na temat możliwości rekonstrukcyjnych jej wczesnogotyckiej fazy.

\section{Przebudowa wczesnogotycka - źródła}

Źródła historyczne odnoszące się do przebudowy katedry dość jasno ukazują inwestycję podjętą przez biskupa Boguchwała II (1242-1253). W „Kronice Wielkopolskiej” jest on przedstawiony jako ten, który podjął rozbiórkę chóru; pod rokiem 1243 zapisano: „kazał z powodu jakiś rysów chór kościoła poznańskiego do gruntu, czyli całkowicie, zburzyć i na nowo zbudować" (Kronika 1965, s. 239). Informację o biskupie Boguchwale II odnotowano również w „Rocznikach Kapituły Poznańskiej” pod rokiem 1253: „Biskup ten w drugim roku swego posługiwania chór i prezbiterium katedry poznańskiej z powodu pewnych pęknięć murów kazał całkowicie wyburzyć i postanowił wznieść nowy fundament i tak rzecz kontynuować" (Roczniki 1995, s. 75). Według tych zapisów można sądzić, że za czasów Boguchwała II rozpoczęto przebudowę katedry. Jednak konsekracja nowego chóru nastąpiła dopiero w 1262 roku, za panowania biskupa Boguchwała III (1254-1264) i to on niewątpliwie finalizował dzieło, co odnotowano w „Roczniku Kapituły Poznańskiej” (Roczniki 1995, s. 91; por. też Nowacki 1959, s. 86, przypis $7^{2}$ ). Sprzeczność w stosunku do powyższych informacji odnajdujemy jedynie w XV-wiecznych „Katalogach biskupów poznańskich” Jana Długosza, we fragmencie odnoszącym się do biskupa Boguchwała II zapisano: „Chór kościoła poznańskiego, znajdujący się w ruinie, wyburzył i od fundamentów wybudował nowy" (Żywoty biskupów 2004, s. 18). Zapewne pomyłka i przypisanie ukończenia działa Boguchwałowi II, a nie Boguchwałowi III nastąpiły ze względu na to samo imię obu biskupów.

Dokumentacja archiwalna z badań i publikowane źródła archeologiczne dotyczące wczesnogotyckiej przebudowy odnoszą się do wydzielenia nawarstwień powstałych $\mathrm{w}$ wyniku prowadzenia prac budowlanych w połowie XIII

2 Tu zapisano: „Zatem w roku pańskim 1262, w dniu św. Piotra [29 VI], brat Witt z zakonu dominikanów, biskup niegdyś litewski, na prośbę pana Boguchwała, biskupa poznańskiego, poświęcił w kościele katedralnym chór od nowa wybudowany. W tym dniu na przyszłość będzie obchodzone wspomnienie konsekracji kościoła". 
wieku, poza tym do detali architektonicznych i odsłoniętych in situ reliktów architektury, które łączone są z tą fazą do czasu budowy nowego, gotyckiego korpusu nawowego w połowie XIV wieku. Podczas badań archeologicznych prowadzonych w 1946 roku wyznaczono warstwę (VII) związaną z przebudową XIII-wieczną chóru (Przewoźna 1959, s. 62-63). Jej zawartość stanowił gruz w postaci okrzesków, fragmentów zaprawy murarskiej, cegieł oraz fragmentów ceramiki z faz C i D wczesnego średniowiecza. Miąższość warstwy wynosiła od 10 do $70 \mathrm{~cm}(54,88-58,28 \mathrm{~m}$ n.p.m.). Odpowiednikiem warstwy VII miała być warstwa IIa odsłonięta podczas badań w latach 50. XX wieku. Uchwycono ją jednak śladowo i domniemanie w wykopie 13 oraz w niektórych sondażach ambitu (Józefowiczówna 1963, s. 132-139, 196), niekiedy nie rozdzielając pozyskanych z niej materiałów archeologicznych od źródeł ruchomych z warstwy przebudowy gotyckiej (warstwa II). Również podczas wspomnianych prac wykopaliskowych nie udało się jednoznacznie wydzielić fundamentów wczesnogotyckiego chóru (ryc. 1: A). Został on wskazany intuicyjnie po zachodniej stronie filaru IX, po południowej stronie filaru XII oraz w wykopie 13. Miały to być dolne fragmenty fundamentu chóru z zachowanymi, wtórnie użytymi starszymi elementami: granitowymi ciosami romańskimi i wielkimi nieobrobionymi głazami, łączonymi silną zaprawą wapienną (Józefowiczówna 1963, s. 120, 138-139). Między kamieniami odnotowano wciśnięte drobne fragmenty cegieł. Na te relikty nałożony został fundament gotycki z użyciem większej ilości cegieł, w niektórych partiach regularnie murowanych. Tu podstawę fundamentu stanowiły nadal wtórnie użyte ciosy romańskie. Strop ewentualnego fundamentu wczesnogotyckiego wyznaczono od głębokości 55,67/54,79 m n.p.m. Witold Gałka publikując plan katedry z naniesionymi reliktami wczesnogotyckimi również nie uzasadnił na jakiej podstawie wykreślił fundamenty chóru (Gałka 2001, ryc. 109). Zaznaczył schematycznie ciąg wczesnogotyckich pozostałości, począwszy od przestrzeni między filarami IX i X, po przestrzeń między filarami XII i XIII, a także od strony południowej przy filarach VI i VII. Przeprowadzana przeze mnie kwerenda archiwalnej dokumentacji z badań nie pozwala na jednoznaczne wydzielenie fundamentowania wczesnogotyckiego: zdjęcia są czarno-białe, robione często pod kątem, a w dokumentacji rysunkowej taki podział nie jest oczywisty.

W 1946 roku odsłonięto wczesnogotyckie przemurowanie na wysokości nawy romańskiej (ryc. 1: B), określone jako „stary mur ceglany” w zachodniej ścianie kaplicy Szołdrskich, w miejscu domniemanego transeptu romańskiego (Józefowiczówna 1963, s. 24, przypis 81). Kamienny romański zachodni mur południowego transeptu zachował się tu do wysokości około $5 \mathrm{~m}$ powyżej posadzki. Stwierdzono, że od strony zachodniej został on oblicowany cegłą; w licu natrafiono na późnoromańskie okno rozglifione uskokiem do wnętrza. Dotychczas nie udało się dotrzeć do dokumentacji fotograficznej lub rysunkowej tej ściany. Z przypisu podanego przez K. Józefowiczównę wynika, że został tylko wykonany szkic autorstwa 
inż. Franciszka Morawskiego, a następnie ścianę tę pośpiesznie zabetonowano i przemurowano nowym licem ceglanym. Jedynie nakaz służb konserwatorskich przy okazji generalnego remontu tej kaplicy mógłby zweryfikować interesujący fragment ściany i fundamentowanie na tym odcinku. Inną interpretację tego reliktu przyjął Jan Zachwatowicz, który zanegował istnienie transeptu na rzecz hipotezy o kaplicy dobudowanej od strony południowej w połowie XIII wieku (Zachwatowicz 1971, s. 154).

Kolejne relikty związane z wczesnogotycką fazą katedry grupują się w nawie południowej, w jej zachodniej części przywieżowej (ryc. 1: C). Rozpoznano tam dwie półkolumny dostawione do filarów romańskich, murowany filar (Józefowiczówna 1963, s. 121-123, 161, 163-165) i ceglane relikty zapewne wschodniego zamknięcia tego układu ${ }^{3}$. Półkolumny zostały dolepione do zachodnich ścian pierwszego i drugiego filara romańskiego (ryc. 2). Ich szerokość wynosi 1,3 m, wymurowano je na łuku koła o średnicy około $1,1 \mathrm{~m}$. W dziennikach robót odnotowano wymiary użytej, wykrawanej ręcznie cegły: $29 \times ? \times 9 \mathrm{~cm}^{4}$. Ceglane doklejki zostały rozebrane na podobną wysokość, co romańskie filary: 56,45 m n.p.m. (zachodnia) i 56,76 m n.p.m. (wschodnia). W półkolumnie zachodniej zachowały się dwa poziomy cegieł, zaś we wschodniej cztery. Murowany filar odsłonięto przy wejściu do pierwszej południowej kaplicy przy wieżach zachodnich (ryc. 3). Dostawiono go na poziomie południowej odsadzki romańskiej ściany obwodowej. Ma on kwadratowy przekrój o wymiarach $1,3 \times 1,3 \mathrm{~m}$, wymurowano go w wątku wedyjskim przy użyciu „dużej” cegły. Był to filar wolno stojący, odsłonięto jego trzy naroża. Na nim nadbudowano filar gotyckiej arkady kaplicy. W odległości 4,12 m na wschód od krawędzi filara (w wątku wendyjskim), w dokumentacji rysunkowej czytelne jest śladowo zachowane ceglane przemurowanie nadbudowane na romańską ścianę obwodową. Jego spąg znajduje się na podobnej głębokości, co spąg opisanego filara, co może wskazywać na pozostałość po filarze arkady lub ścianie zamykającej od wschodu układ omawianych reliktów.

W nawie północnej zarejestrowano natomiast szczątkowo zachowane relikty ceglane w wewnętrznym licu północnego, romańskiego muru obwodowego (ryc. 1: D). „Nalepione na koronie kamiennego muru romańskiego fragmenty murków ceglanych o niejasnym przeznaczeniu. Zachowane w stanie szczątkowym, mieszczą się w czterech punktach muru w dość regularnych odstępach (3,1-3,2 m), tworząc w murze kubiczne bloki z prostokątnymi występami o $25 \mathrm{~cm}$ przed lico południowe, sugerującymi, iż stanowiły podstawę pilastrów. Wykonane z cegły palcówki na zaprawie wapiennej. Górna niwelacja waha się od -26 do $-73 \mathrm{~cm}$ [57,41-56,94 m n.p.m.]. Stwierdzono proste ściany tych bloków od stron zachodniej,

\footnotetext{
${ }^{3}$ Zaznaczone w dokumentacji rysunkowej (kwerenda archiwalna).

${ }^{4}$ Dzienniki robót z 1951 roku, $\mathrm{nr}$ inw. MAP-A-IAiE 4/26/4, s. 84-85; tu również sugestia zmiany systemu stropowego na sklepienny.
} 


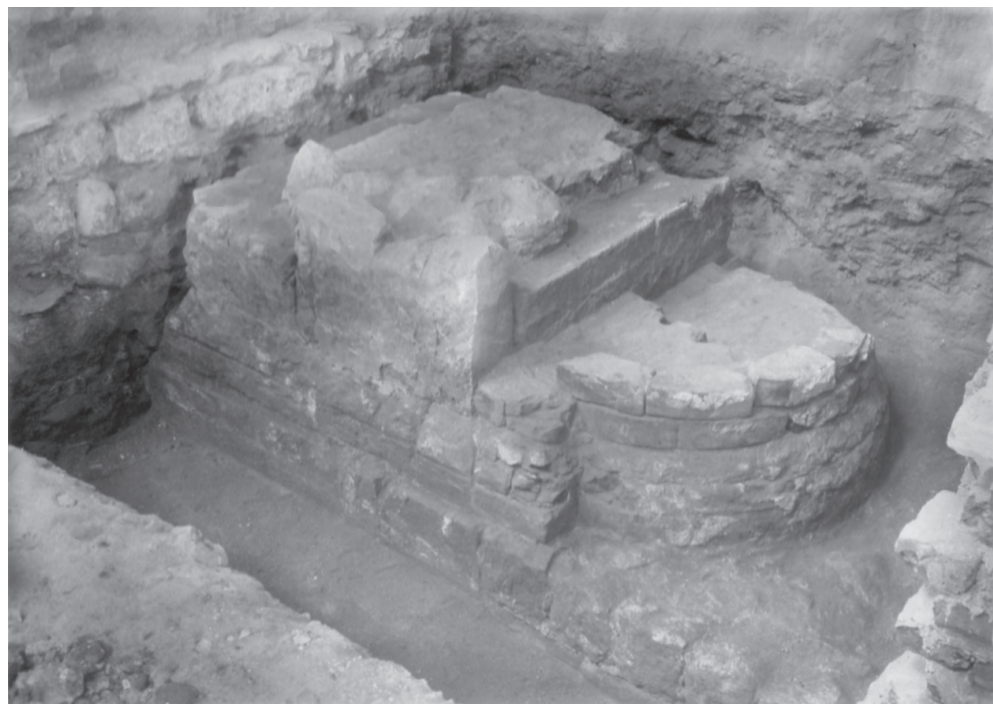

Ryc. 2. Poznań, Ostrów Tumski. Półkolumna dostawiona do drugiego filara romańskiego katedry (fot. K. Józefowiczówna; ze zbiorów Miejskiego Konserwatora Zabytków w Poznaniu)

Fig. 2. Poznań, Ostrów Tumski. Engaged column attached to the second pillar of the Romanesque cathedral (photo K. Józefowiczówna; from the collection of the City Heritage Conservator's Office in Poznań)

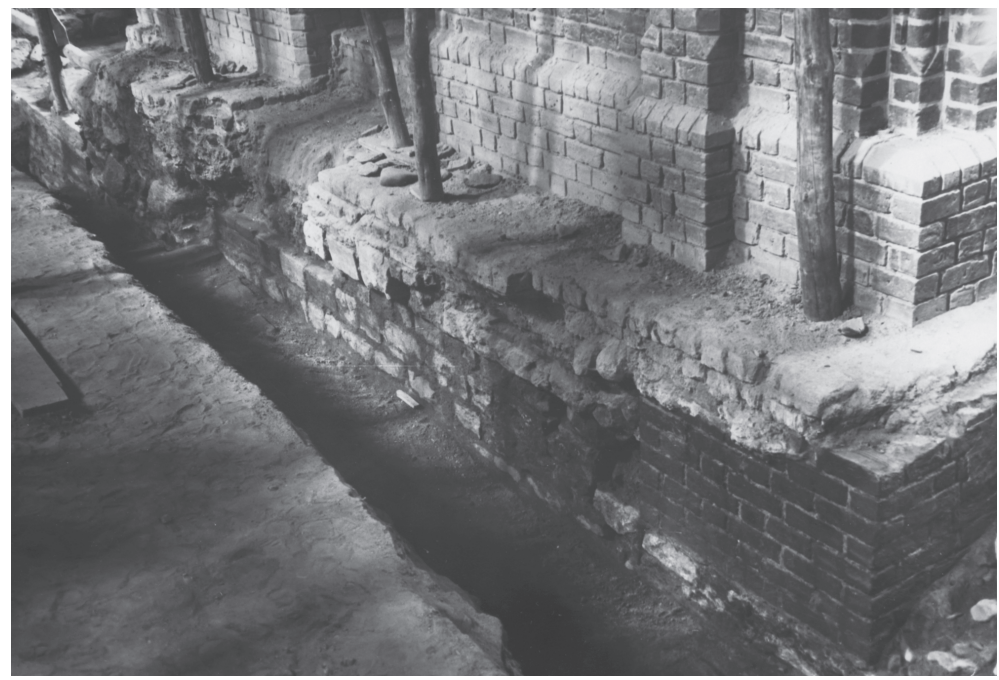

Ryc. 3. Poznań, Ostrów Tumski. Wolnostojący filar w wątku wendyjskim (ze zbiorów Miejskiego Konserwatora Zabytków w Poznaniu)

Fig. 3. Poznań, Ostrów Tumski. Free-standing pillar in Wendish bond (from the collection of the City Heritage Conservator Office in Poznań) 
wschodniej i południowej, wiązanie cegieł w licu wedyjskie" (Józefowiczówna 1963 , s. 122 , 145, ryc. 38).

W kontekście trwającej dyskusji nad rekonstrukcją wschodniej części katedry wczesnogotyckiej wspomnieć należy jeszcze o wątku wedyjskim odnotowanym w dolnych partiach murów północnej zakrystii prałackiej św. Stanisława (ryc. 4: A), po zewnętrznej północno-wschodniej stronie Złotej Kaplicy (ryc. 4: B) oraz w południowej kaplicy kapitulnej (ryc. 4: C) (Linette 1988, s. 100; Gałka 2001, s. 43, ryc. 109). W Złotej Kaplicy zachował się starszy fundament i skute lico muru pochodzące $\mathrm{z}$ tego samego czasu, co relikty odsłonięte na ścianie zakrystii prałackiej. Lico starszego muru wysunięte było na około $1 \mathrm{~m}$ przed lico współczesne. Dokumentację fotograficzną i rzetelne opisy posiada jedynie mur zakrystii prałackiej (Gałka 1990, s. 4-5, fot. 2, 5).

Odnośnie wyposażenia katedry wczesnogotyckiej wiadomo, że posiadała ołtarz główny w prezbiterium i ołtarz św. Trójcy, zapewne jeszcze romański, stojący we wschodniej części nawy głównej, w odległości 0,8 m od linii gotyckich filarów tęczy. Fundament ołtarza głównego (ryc. 1: E) zbudowany został przy użyciu cegieł i małych oraz średnich kamieni łącznych zaprawą; jego spąg odnotowano na głębokości 54,97 m n.p.m. (Józefowiczówna 1963, s. 196, ryc. 126-127). Według dokumentacji zajmował on powierzchnię $10,8 \mathrm{~m}^{2}$, boki osiągały długość około 2,7 i 4 m. Za ołtarz św. Trójcy (ryc. 1: F) uważa się częściowo zachowany kamienny fundament wykonany z granitowych „okrąglaków” i ciosów wiązanych zaprawą wapienną (Józefowiczówna 1963, s. 17, 119, 185, przypisy 49-50, ryc. 113-114). Strop fundamentu znajdował się na głębokości 56,59 m n.p.m., zaś spąg na głębokości 55,40 m n.p.m. Zachowane wymiary tego masywnego reliktu zniszczonego przez wkopy grobowe wynoszą: 3,2 m na osi wschód-zachód i 4,7 m na osi północ-południe. Fundament został wkopany w warstwę III (romańską), przecinały go wkopy grobowe zalegające w warstwie II.

Podstawowe informacje dotyczące katedry wczesnogotyckiej zostały pozyskane dzięki kamiennym detalom budowlanym. Kamieniarka reprezentowana jest raczej skromnie; wymienić tu można znane już ze starszej literatury dwa piaskowcowe kapitele katedralne (Józefowiczówna 1963, s. 135-136, 186, ryc. 32, 119). Jeden, z przyściennego pilastra z półkolumną o prostej formie oraz dwoma mniejszymi kapitelikami po bokach większego, ma formę prostokątnego gzymsu z wklęsłym uskokiem biegnącym do okrągłego wałka wieńczącego kolumnę (ryc. 5). Wspierał zapewne gurt lub żebro sklepienne. Detal ten zarejestrowano w wykopie sondażowym założonym w ambicie, po północnej stronie katedry; zalegał w warstwie gotyckiej. Drugi to kapitel kielichowy z naturalistycznie wykonaną dekoracją w postaci liści dębu (ryc. 6). Jego kątowe uformowanie tylnej, stycznej ze ścianą strony skłania do przyjęcia hipotezy o wielobocznie zamkniętym chórze. Kapitel ten odkryto w XV-wiecznym fundamencie ławy rozporowej na linii tęczy, gdzie został użyty wtórnie jako gruz budowlany. Również on 


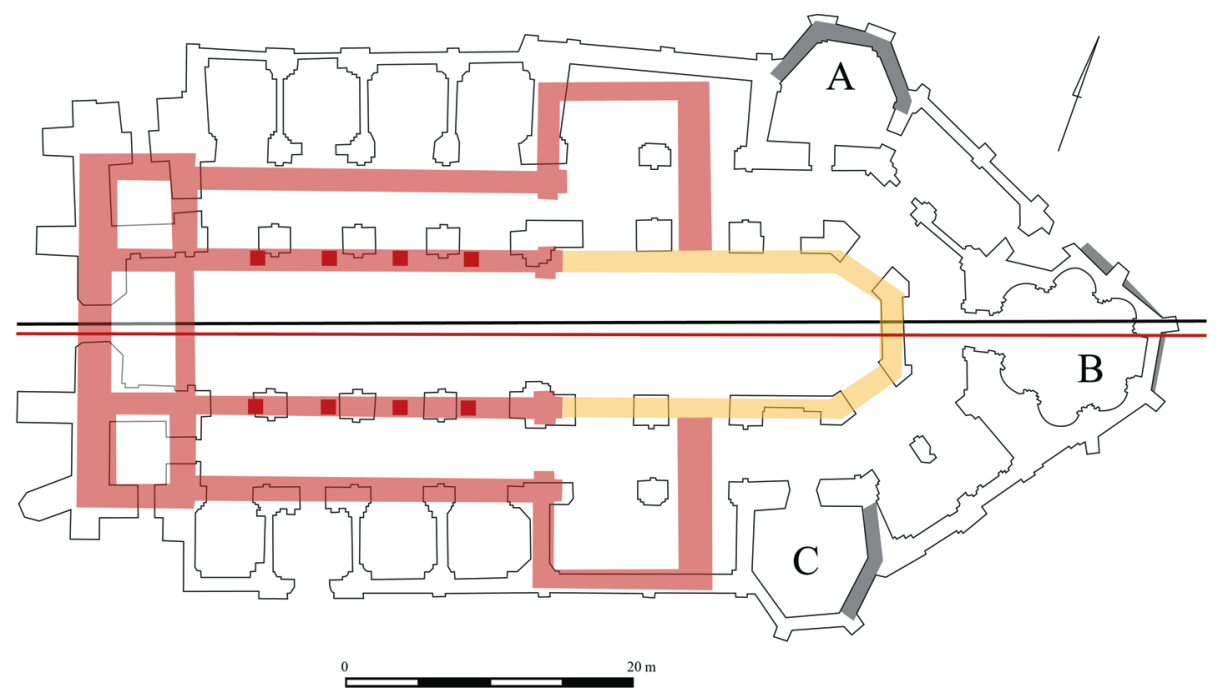

Ryc. 4. Poznań, Ostrów Tumski. Zmiana osi katedry, zaznaczono domniemane wczesnogotyckie fragmenty murów i fundamentów. A - kaplica prałacka św. Stanisława, B - kaplica mansjonarska (obecna Złota Kaplica), C - kaplica kapitulna (rys. W. Gorączniak; wg Józefowiczówna 1963, Gałka 2001)

Fig. 4. Poznań, Ostrów Tumski. Change of the cathedral axis, marked by the suspected early Gothic walls and foundations. A - prelate chapel of St Stanislaus; B - a mansionary chapel (currently the Golden Chapel); $\mathrm{C}$ - chapter chapel (drawing W. Gorączniak; after Józefowiczówna 1963, Gałka 2001)

miał pełnić funkcję konstrukcyjną w systemie sklepiennym wczesnogotyckiego chóru. Podobny stylistycznie jest również niewielki fragment kamieniarki z badań w 1999 roku, zarejestrowany po południowo-zachodniej stronie kościoła pw. Najświętszej Marii Panny (ryc. 7) (Kóčka-Krenz 2000, s. 71). Niestety, dokładny kontekst jego zalegania nie jest znany (wykop 2, hałda). Zachowała się tylko część detalu architektonicznego wykonanego z piaskowca o płaskim spodzie i dolnym fragmencie przypominającym liść figowca/klonu(?); jego długość wynosi około $14 \mathrm{~cm}$, zaś szerokość około $7,7 \mathrm{~cm}$. W piaskowcu oddano bardzo realistycznie kształt liścia wraz z unerwieniem i zagiętym ogonkiem. Wierzch detalu został starannie opracowany i wygładzony, natomiast boki noszą ślady obróbki bardzo cienkim dłutkiem (szerokość około 1,5 mm). Z dużym prawdopodobieństwem można przyjąć, że jest to kolejny fragment dekoracji katedry wczesnogotyckiej, trudno jednak wskazać z jakiego elementu konstrukcyjnego pochodzi. Wyraźny łuk na obrzeżu raczej sugeruje, że jest to część zwornika albo archiwolty portalu.

Poszukując kamieniarzy pracujących przy wczesnogotyckiej katedrze Eugeniusz Linette zwrócił uwagę na podobieństwo opracowania roślinności 

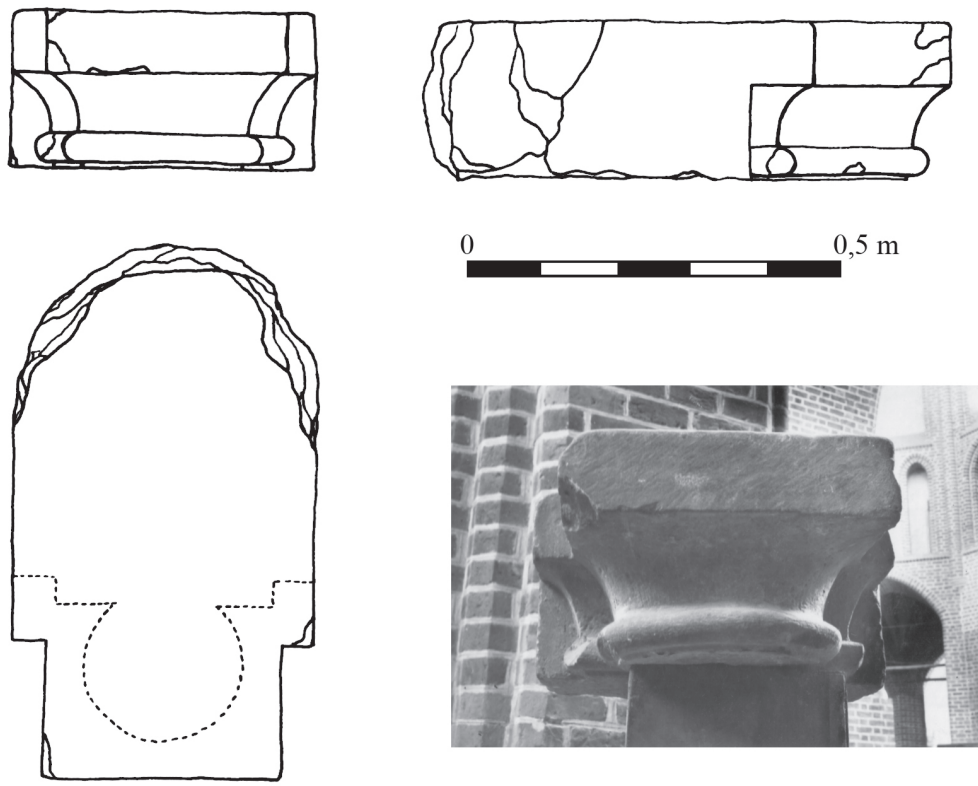

Ryc. 5. Poznań, Ostrów Tumski. Kapitel pilastra z piaskowca (ze zbiorów Miejskiego Konserwatora Zabytków w Poznaniu; fot. K. Józefowiczówna; rys. wg Józefowiczówna 1963)

Fig. 5. Poznań, Ostrów Tumski. Sandstone pilaster capital (from the collection of the City Heritage Conservator's Office in Poznań; photo K. Józefowiczówna; drawing after Józefowiczówna 1963)

w przypadku kapitelu katedralnego oraz wczesnogotyckich zworników w kościele podominikańskim przy ul. Szewskiej w Poznaniu (Linette 1959). Szerszą interpretację przyjął Szczęsny Skibiński zakładając, że ci sami wykonawcy działali zarówno w kościele dominikańskim oraz chórze katedry poznańskiej, jak i katedry wrocławskiej (Skibiński 1996, s. 49-51; 2001, s. 35-37). Od lat w środowisku historyków sztuki proweniencja warsztatu kamieniarskiego wzbudzała wiele emocji naukowych i dyskusji. Marian Kutzner uważał, że forma wspomnianego kapitelu ,wskazuje wyraźne ślady współzależności od zespołu kamieniarzy środowiska saskiego, pracujących na wzorach rzeźbiarzy francuskiego gotyku klasycznego" (Kutzner 1969, s. 376). Eugeniusz Linette widział podobieństwo stylistyczne rzeźb z kościoła dominikańskiego i katedry poznańskiej z chórem zachodnim katedry w Naumburgu i chóru w Miśni, podobnie jak M. Kutzner brał pod uwagę wzorce saskie (Linette 1959, s. 354). Dopiero S. Skibiński zauważył szersze i bardziej złożone przyczyny pojawienia się w tym samym czasie podobieństw w detalu architektonicznym ziem niemieckich, Poznania i Wrocławia, co znalazło uznanie w środowisku osób zajmujących się badaniami 

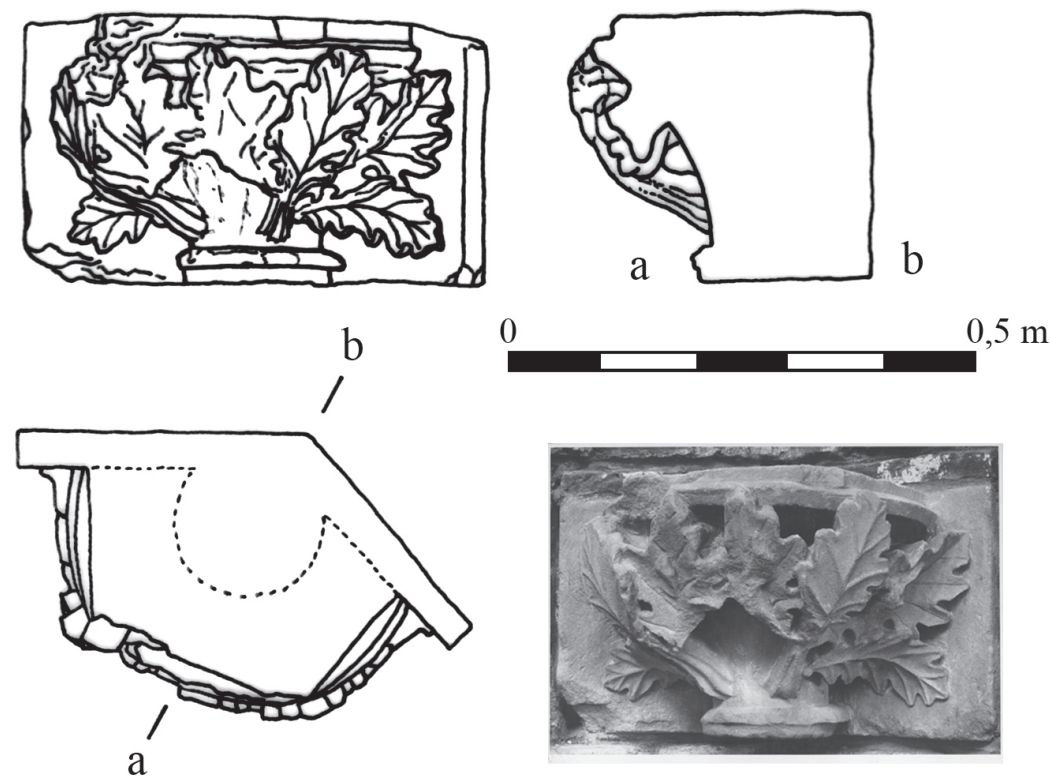

Ryc. 6. Poznań, Ostrów Tumski. Kapitel z piaskowca z liśćmi dębu (ze zbiorów Muzeum Archeologicznego w Poznaniu; fot. K. Józefowiczówna; rys. wg Józefowiczówna 1963)

Fig. 6. Poznań, Ostrów Tumski. Sandstone capital with oak leaves (from the collection of the Museum of Archaeology in Poznań; photo K. Józefowiczówna; drawing after Józefowiczówna 1963)

nad architekturą katedry wczesnogotyckiej (Skibiński 1996, s. 49-51; 2001; 2003; 2005). Według cytowanego badacza był to skutek kryzysu ekonomicznego we Francji, spowodowanego krucjatami i nagłym brakiem zatrudnienia dla licznych strzech budowlanych. Kiedy po upadku Jerozolimy w 1244 roku król Ludwik IX Święty zaczął gromadzić fundusze na organizację kolejnej krucjaty, ograniczono i wstrzymano wielkie i mniejsze inwestycje budowane na terenie Francji. Wówczas wielu rzeźbiarzy i kamieniarzy straciło zatrudnienie, stąd ich migracje do krajów sąsiednich w poszukiwaniu pracy. Podobne formy rzeźbiarskie pojawiły się w tym samym czasie na ziemiach niemieckich, jak i na ziemiach polskich. Szczęsny Skibiński przytacza tu przykłady zwornika z liśćmi dębu ze sklepienia nawy głównej kościoła benedyktynów z Saint-Deni oraz zwornika z liśćmi wyciętymi trójlistnie ze sklepienia kościoła cystersów w L'Epau (Skibiński 2004, ryc. 9, 10). Przypuszczalnie inspiracją dla wielobocznie zamkniętego chóru katedry poznańskiej i motywów roślinnych kamieniarki mogła być Sainte-Chapelle w Paryżu. 

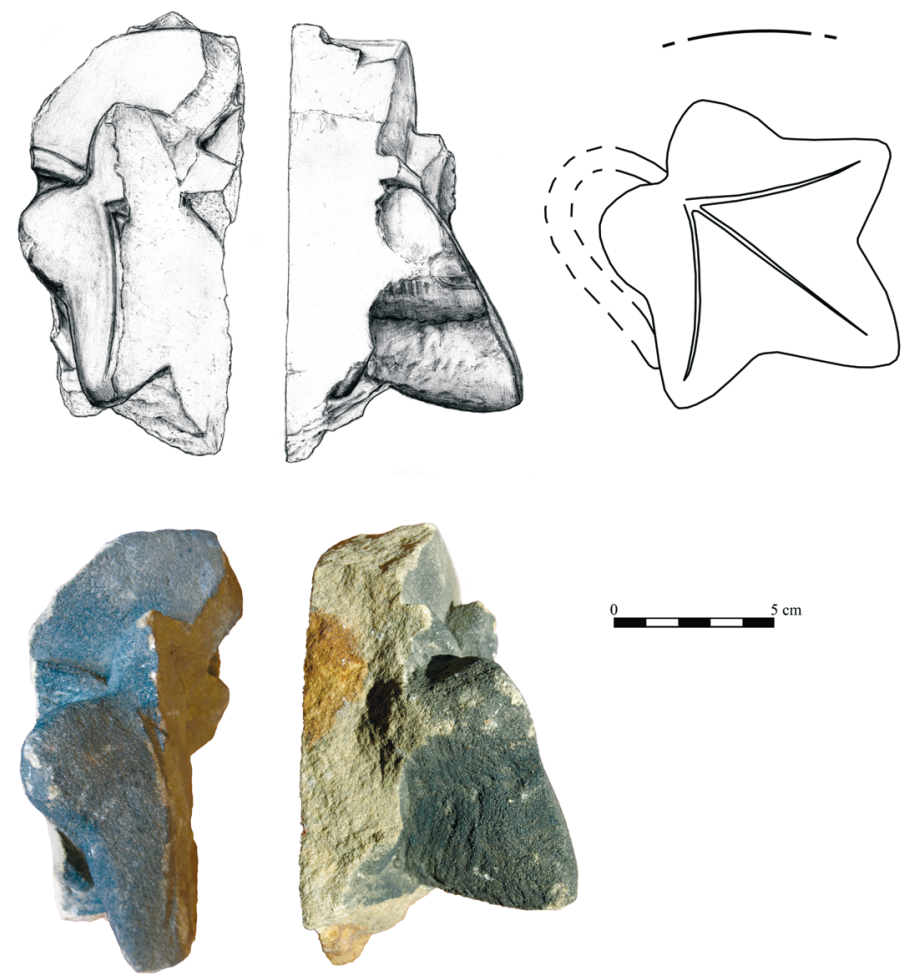

Ryc. 7. Poznań, kościół pw. Najświętszej Marii Panny. Liść z piaskowca z okolic kościoła (rys. O. Antowska-Gorączniak, fot. O. Antowska-Gorączniak)

Fig. 7. Poznań, Our Lady's church. Sandstone leaf from the church area (drawing O. Antowska-Gorączniak, photo O. Antowska-Gorączniak)

\section{Interpretacje i rekonstrukcje}

Z opisów rekonstrukcji chóru wczesnogotyckiego wynika, że został on wzniesiony przy użyciu cegieł i kamienia (Józefowiczówna 1963, s. 121; Zachwatowicz 1971, s. 154). O ile znane są pojedyncze XIII-wieczne detale kamienne, tak o wczesnogotyckiej cegle katedralnej nic nie wiemy, bowiem nie wykonano pomiarów cegieł i nie pobrano jej wraz z materiałem ruchomym. Jednak patrząc z perspektywy ceglanej architektury Poznania i mając na uwadze fakt pojawienia się około połowy XIII wieku pierwszych wykonanych w tym materiale murów, powyższe założenia wydają się jednak słuszne. W 2011 roku odsłonięto przemurowane wtórnie w cegle główne wejście do książęcego palatium ${ }^{5}$ (średnie

5 Badania Instytutu Prahistorii Uniwersytetu im. Adama Mickiewicza pod kierunkiem prof. dr hab. Hanny Kóčki-Krenz, dokumentacja i materiały znajdują się w Instytucie Prahistorii UAM. 
wymiary cegieł: $25 \times 11,6 \times 9,4 \mathrm{~cm})$ i z dużym prawdopodobieństwem do tej naprawy należałoby odnieść tekst z „Kroniki Wielkopolskiej”, gdzie pod rokiem 1249 zapisano: „dux Przemisl readificavit castrum et civitatem Posnaniensem circa ecclesiam majorem" (Monumenta 1932, s. 572). Również wśród zachowanych budowli z cegły wykonany jest dawny kościół dominikanów i kościół joannitów św. Jana Jerozolimskiego na Komandorii, którego bryła wykazuje jeszcze cechy późnoromańskie. Budowa pierwszego z nich miała miejsce w tym samym czasie, co opisana przebudowa chóru katedralnego; wymurowano go z cegieł o wymiarach 24-26×11-12 × 8-9 cm (Linette 1953, s. 469). Co do datowania kościoła joannitów nadal trwa dyskusja czy powstał on w miejscu starszego, kamiennego obiektu około połowy XIII wieku, czy nawet w 3. ćwierci XIII wieku (Świechowski 1961, s. 92; Krzyślak, Kurzawa 2011, s. 5), czy już na przełomie XII i XIII wieku (Gałka 2001, s. 35-36). Cegła z tej budowli jest zdecydowanie większa i niższa; jej wymiary wynoszą: $30 \times 13,5-15 \times 7 \mathrm{~cm}$ (Świechowski 1961, s. 122).

Wracając do katedry wczesnogotyckiej, to wszyscy badacze ${ }^{6}$ są zgodni co do jednego - w połowie XIII wieku został wybudowany nowy, wielobocznie zamknięty (kapitel z liśćmi dębu) chór ze sklepieniem, w miejscu poprzedniego chóru katedry romańskiej. Dobudowany został do stojącego XI-wiecznego korpusu nawowego. W. Gałka próbował zrekonstruować przyścienne kolumny z odchodzącymi od nich żebrami sklepiennymi (Gałka 2001, ryc. 47). Ciągle dyskutuje się wokół faktu, jak bardzo była rozbudowana przestrzeń prezbiterium. Część badaczy to zwolennicy bardzo zawężonej inwestycji XIII-wiecznej przebudowy. Zakładają oni istnienie romańskiego korpusu, do którego dobudowano wielobocznie zamknięty chór bez żadnych pomieszczeń, wykluczają obecność obejścia i tym samym dobudowanych do niego kaplic (Skibiński 2001, s. 32-35; Kowalski 2010, s. 19-22).

Pierwsza badaczka katedry, K. Józefowiczówna, uważała, że budowla posiadała wielobocznie zamknięty chór zbudowany na planie i być może fundamentach chóru romańskiego (ze względu na statykę nie ingerowano w partię fundamentów chóru), plan ten później powtórzony został w katedrze gotyckiej. Jej zdaniem inwestycja ta odnosiła się również do innych elementów katedry. Do takiej hipotezy K. Józefowiczównę skłoniła znajdująca się w „Rocznikach Kapituły Poznańskiej” informacja o przebudowie chóru i prezbiterium (chorum et sanktuarium); autorka twierdziła, że określenie chorum ma szersze znaczenie i odnosi się do części chóru i przyległych pomieszczeń: transeptu, zakrystii, ambitu i dostawionych do niego kaplic (Józefowiczówna 1963, s. 16). Badaczka widziała między innymi przebudowę transeptu romańskiego w fazie wczesnogotyckiej, co jest czytelne w partii murów w ścianie zachodniej wspomnianej wyżej kaplicy Szołdrskich i na tej samej linii od północnej strony katedry, w zachodniej stronie (kaplica Górków). Katedra miałaby swym rzutem obejmować nawę główną (romańską), dobudowany

${ }^{6}$ Ostatnio wielokątność zamknięcia wczesnogotyckiego chóru katedry poznańskiej zanegował Janusz Tomala i zignorował tym samym fakt obecności kapitela z liśćmi dębu o ukształtowanej rozwartokątnie tylnej ścianie (Tomala 2007, s. 82). 
chór i transept zakończony kaplicami na linii łuku tęczowego (obecna kaplice Górków i Szołdrskich). Krystyna Józefowiczówna odrzucała jednak istnienie obejścia z otwartymi do niego kaplicami; dopuszczała funkcjonowanie u schyłku XIII wieku kaplicy Królewskiej. W tym kontekście badaczka odczytała funkcję dwóch półkolumn, zarejestrowanych na przejściu do nawy południowej, jako wyprowadzonych do pewnej tylko wysokości cokołów pod rzeźby statuaryczne (zapewne w odniesieniu do wspomnianych w XIV-wiecznym zapisie Kronik Jana z Czarnkowa (Jan z Czarnkowa 1996, s. 41) zniszczonych imagines królewskich; Józefowiczówna 1963, s. 121-122, 164-165). Natomiast wolno stojący filar miałby podtrzymywać arkady wejścia do bocznej kaplicy. Wspomniany relikt ceglany oddalony o około 4,4 m od tego filara zapewne był zamknięciem od wschodu dwuarkadowego przejścia do kaplicy.

Kolejni badacze uzasadniali istnienie chóru wraz z obejściem (Kutzner 1969; Gałka 2001; Kusztelski 2003). Dodatkowo uznali istnienie otwartych na ambit kaplic: kapitulnej (od południa), zakrystii św. Stanisława (od północy) i Złotej Kaplicy (od wschodu); w ich ścianach w ostatnich latach rozpoznano przemurowanie w wątku wedyjskim. Andrzej Kusztelski przedstawił niedawno hipotetyczny schemat narastania kaplic od schyłku XIII do XV wieku (Kusztelski 2003, ryc. 8). Jak wiadomo, wątek wendyjski nie jest wyznacznikiem, że te fragmenty ścian powstały w ramach wieku XIII, ale nierównomierność rozstawienia kaplic może sugerować istnienie obejścia już we wspomnianym stuleciu. W kontekście tych rozważań nikt nie zwrócił uwagi na problem głównej osi katedry i jej przesunięcia, które może tłumaczyć nierównomierność lokalizacji kaplic, a w szczególności zauważane odchylenie na południe obecnej Złotej Kaplicy. Wprawdzie zajmujący się problemem badacze wspominali ogólnie o postawieniu ich na jakiś starszych fundamentach/murach, to jednak nikt nie zadał pytania dlaczego taka sytuacja ma miejsce ${ }^{7}$. Odchylenie to można dość logicznie wytłumaczyć, jeśli się spojrzy jednocześnie na zarys katedry romańskiej z dobudowanym XIII-wiecznym chórem i przebudowany w XIV wieku korpus nawowy (ryc. 4). Katedra wczesnogotycka (jej dobudowany w połowie XIII wieku chór) miała wspólną oś z nawą (jeszcze romańską). Złota Kaplica wykazuje zgodność osi z chórem wczesnogotyckim i tym samym z romańskim korpusem. Wielka przebudowa z połowy XIV wieku, obejmująca przede wszystkim partię nawową, spowodowała zmianę szerokości naw, z wyraźnie większym przesunięciem ściany obwodowej północnej i północnego rzędu filarów. Zmieniono wówczas główną oś całego budynku - została ona

${ }^{7}$ Krytycznie odnoszę się przy tym do przedstawionej przez J. Tomalę (2007, s. 68-69) tezy o wymiarze czysto symbolicznego odchylenia osi nawy i prezbiterium niektórych budowli. Wyklucza on skrzywienia wynikające $z$ etapowości stawiania fundamentów i murów (nakładania się wielu faz budowlanych) na rzecz symboliki Chrystusa ukrzyżowanego. Z własnego, kilkunastoletniego doświadczenia zdobytego podczas terenowych prac archeologiczno-architektonicznych wiem, że prawie za każdym razem odchylenie osi ścian budynków spowodowane jest narastaniem kolejnych faz rozbudowy. 
przesunięta ponad $1 \mathrm{~m}$ na północ, z nieznacznym odchyleniem części wschodniej na południe (osie te nie są równoległe - po stronie wschodniej odejście osi wynosi około 1,3 m, po stronie zachodniej około $0,8 \mathrm{~m}$ ). Sądzę, że to kolejny dowód - poza stwierdzeniem wątku wedyjskiego w zakrystii prałackiej, Złotej Kaplicy i kaplicy kapitulnej - że obejście powstało jeszcze wtedy, kiedy istniał chór wczesnogotycki i właśnie on determinował odchylenie wschodniej kaplicy w stronę południową. Wydaje się więc, że w trakcie wspomnianej przebudowy nie rozebrano wczesnogotyckiego chóru (miał on inną oś), ale zostało dobudowane obejście i trzy wspomniane kaplice (pozostałości ścian w wątku wedyjskim). Zapewne obejście od strony północnej starano się w jakimś stopniu dopasować do już przebudowanego korpusu nawowego. Być może również z tego czasu pochodzi ingerencja w ściany transeptu. Brak wspólnej osi chóru i nawy głównej przyczynił się zapewne do poszukiwań stabilności konstrukcji, a to spowodowało niesymetryczność układu kaplic południowych, bardziej regularnych i północnych o nieregularnych planach płaskich. Obecna Złota Kaplica wymurowana została na tej samej osi co chór wczesnogotycki. Dopiero przebudowa z przełomu XIV i XV wieku znów wprowadziła wspólną oś dla części chóru z tryforiami i korpusu nawowego z połowy XIV wieku, a nierównomierne rozmieszczenie kaplic obejścia stanowi trwały ślad po przebudowie sprzed półwiecza (na ich fundamenty nałożono nowe mury już w wątku gotyckim). Przedstawiając powyższe dowody przychylam się do głosu drugiej grupy badaczy (Kutzner 1969, s. 376; Gałka 2001; Kusztelski 2003).

Kolejnym problemem historii budowlanej katedry są rytmiczne relikty ceglane nadbudowane na romańską północną ścianę obwodową. Krystyna Józefowiczówna opowiadała się za wymurowaniem ich dopiero po połowie XIV wieku, a więc po wielkiej przebudowie gotyckiej korpusu; interpretowała je jako pozostałości bocznych ołtarzy, zanim w XV wieku zostały dostawione kaplice. Może jednak trzeba wziąć pod uwagę próbę (pytanie czy sfinalizowaną) przesklepienia przynajmniej bocznych naw (samej nawy północnej?). Pozostawiono mury obwodowe romańskiej katedry, a jedynie w rozprute przestrzenie, mniej więcej na linii filarów romańskich, wymurowano wystające przed mury pilastry ceglane będące oparciem dla wyprowadzenia łuków sklepienia. Jeśli przyjąć to rozwiązanie, inwestycję tę należy odnieść do okresu po połowie XIII wieku, a przed wielką XIV-wieczną przebudową gotycką (połowa XIV wieku).

\section{Sepulkralny charakter katedry}

Katedra poznańska była miejscem pochówków przede wszystkim biskupów poznańskich i duchowieństwa oraz według tradycji (i nielicznych źródeł historycznych) książąt i królów, do czasów Przemysła II (†1296 rok). Jeśli archeologicznie można było potwierdzić, dzięki atrybutom (pierścień, patena, kielich, pastorał), pochówki biskupie, to jednoznacznie nie udało się wskazać grobów władców. 
W wielu przypadkach ich szczątkowa obecność jest dyskusyjna - choćby grobowce pierwszych władców piastowskich: Mieszka I i Bolesława Chrobrego. O pochówkach Mieszka I, Bolesława Chrobrego, Mieszka II, Kazimierza Odnowiciela, Władysława Odonica i Bolesława Pobożnego dowiadujemy się dopiero z późnej, bo z XV-wiecznej kroniki Jana Długosza (informacje miały być zapisane na podstawie tradycji). Zawiera ona wzmiankę, że Władysław Odonic nadawał przywileje katedrze poznańskiej będąc do niej „gorąco przywiązany” z powodu tego, że tu ,pochowani spoczywają ojciec jego Odo i Bolesław Wielki i inni jego przodkowie” (Kronika 1965, s. 111-212). Zdaniem części badaczy „Kronika wielkopolska" powstała u schyłku XIII wieku, według innych w 2. połowie XIV wieku, zatem fragment ten mógł być zainspirowany XIV-wiecznym sarkofagiem pierwszego króla. Dopiero pochówki w katedrze poznańskiej ostatnich Piastów wielkopolskich: księcia Przemysła I i króla Przemysła II oraz jego drugiej żony Ryksy znajdują odzwierciedlenie w kilku źródłach pisanych bezpośrednio w XIII wieku. W przywileju wydanym przez Przemysła I 24 kwietnia 1252 roku w Gnieźnie czytamy: „Książę Przemysł I wybierając katedrę poznańską jako miejsce wiecznego spoczynku uwalnia mieszkańców wsi będących własnością katedry od ciężarów prawa polskiego [...]" (Przywileje 1994, s. 2). Podczas nadania biskupowi poznańskiemu wsi Kobylniki i terenu Śródki przez Przemysła II 19 kwietnia 1293 roku zapisano: „[...] Biskup, znając cześć, jaką książę żywi dla katedry poznańskiej, zobowiązuje się palić świece we wszystkich godzinach kanonicznych, a w nocy lampkę olejną na grobie zmarłej żony księcia, a w przyszłości także na jego grobie" (Przywileje 1994, s. 16). Kolejne wzmianki o grobie Przemysła II i jego żony odnajdujemy w kronice Jana z Czarnkowa. Wynika z nich, że w 1371 roku (23 III) na skutek uderzenia pioruna w wieżę południową został strącony krzyż z jej hełmu i jeden z narożników, który przebił dach i sklepienie kaplicy królewskiej, zniszczył zawieszone w niej portrety królewskie (Jan z Czarnkowa 1996, s. 41). Inną koncepcję na temat miejsca pochówku Przemysła II i Ryksy zaprezentował S. Skibiński dowodząc, że pierwotnie znajdował się on pośrodku nawy głównej, tam też miała być palona wieczna lampa (Skibiński 1995, s. 168). Jednak już około połowy XIV wieku rozpoczęło się stawianie w tym miejscu tumby Bolesława Chrobrego, w związku z czym wcześniej przeniesiono pochówki (lub same wyobrażenia i płytę) do wybudowanej kaplicy przy wieży południowej. Tak uhonorowana pomnikiem pamięć o pierwszym władcy miała wyprzeć wspomnianienia o Przemyśle II i Ryksie. Wzmianka z 1371 roku zawarta w kronice Jana z Czarnkowa informowała zatem o zniszczeniu wtórnych (symbolicznych?) pochówków - wyobrażeń królewskich. Z dużym prawdopodobieństwem należy wiązać relikty półkolumn ceglanych i ceglanego filara $\mathrm{z}$ wybudowaną $\mathrm{u}$ schyłku XIII lub w 1. połowie XIV wieku kaplicą królewską Przemysła II i Ryksy

${ }^{8}$ Inne datowanie tych reliktów - na 1. połowę XIII wieku - uwzględnia w katalogu Zygmunt Świechowski (zapewne chodzi tu o okres około połowy XIII wieku). Autor nie podaje interpretacji tych konstrukcji, jak również nie uwzględnia filaru w wątku wedyjskim (Świechowski 2000, s. 198). 


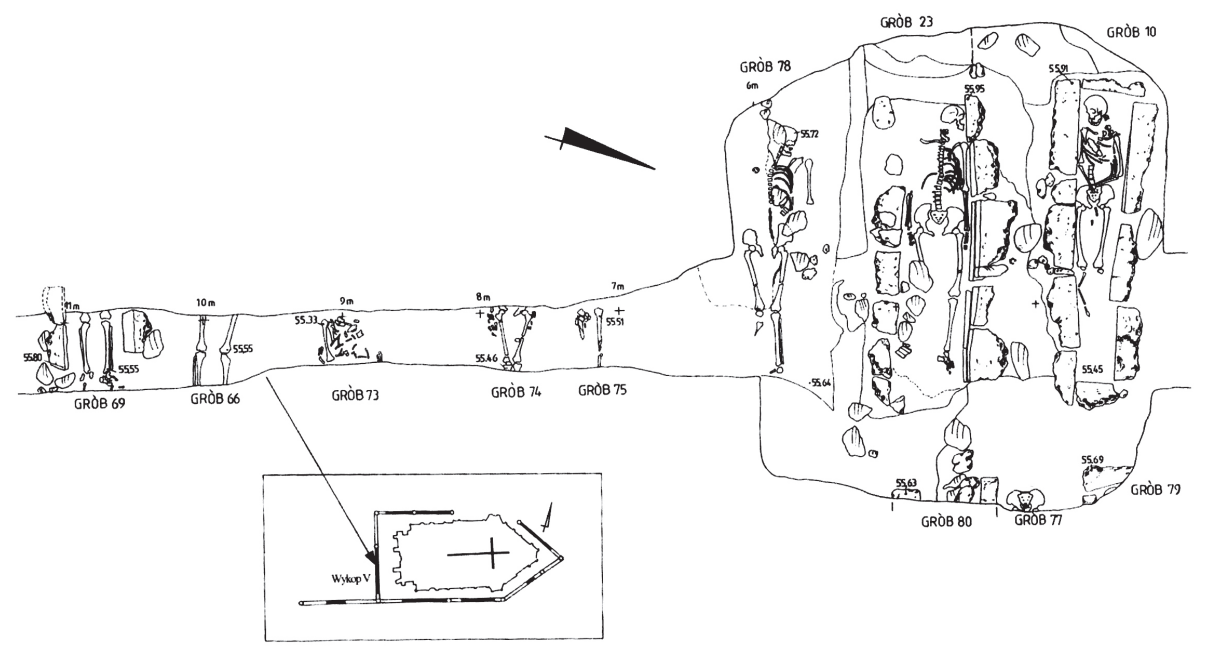

Ryc. 8. Poznań, Ostrów Tumski. Cmentarz przed katedrą (wg Pawlak 2003)

Fig. 8. Poznań, Ostrów Tumski. Cemetery in front of the cathedral (after Pawlak 2003)

W starszej literaturze nie włączono w zakres rozważań dotyczących półkolumn filaru w wątku wedyjskim, a same półkolumny zinterpretowane zostały jako dodatkowe arkady międzynawowe (Zachwatowicz 1971, s. 154).

Do pochówków wczesnogotyckich zaliczono 43 groby zalegające w warstwie II (i grób 126 z warstwy III), w przypadku 23 zarejestrowano zarysy trumien drewnianych, 6 miało formę obudowanego grobowca ceglanego, 3 posiadały obstawy: kamienną, ceglaną i kamienno-ceglaną (Józefowiczówna 1963, aneks). Datowanie pochówków budzi szereg wątpliwości metodycznych i konieczna jest ponowna weryfikacja materiałów oraz dokumentacji z badań, choć rodzi się pytanie czy da pożądany skutek, jeśli w grobach nie było najczęściej wyposażenia i materiałów ruchomych lub ze względu na tempo prac nie były one zbierane. W tym miejscu trzeba przypomnieć, że w trakcie prac wykopaliskowych z lat 50. XX wieku natrafiono na pochówek (grób nr 126), który udało się imiennie zidentyfikować. Obok pastorału, pateny i fragmentów kielicha natrafiono w nim na pierścień pieczętny z napisem na otoku: S BOGUPHALI EP POZN, który wskazuje na właściciela - biskupa Boguchwała II lub Boguchwała III, fundatorów wczesnogotyckiego chóru (Józefowiczówna 1963, s. 207, ryc. 153-154; Sztuka polska 1971, s. 750; Katalog 1983, s. 51, fot. 592). Na prawej dłoni zmarłego znajdował się przedmiot o tarczce ze złoconej blachy w kształcie migdała; widniała na niej litera $\mathrm{H}$ z wpisanym w nią znakiem krzyża (być może to połączenie i stylizacja napisu IHS), a na otoku imię biskupa. Pochówek zarejestrowano w nawie południowej na wysokości czwartej kolumny romańskiej. 
Śladem po rozbiórce romańskiego chóru i budowie nowego są pochówki szkieletowe zarejestrowane wewnątrz oraz przed katedrą, z charakterystyczną obstawą wzniesioną z wykorzystaniem ciosanych kamieni porozbiórkowych. Dwa z nich, należące do biskupów, odnotowano we wnętrzu katedry, pięć kolejnych przed fasadą zachodnią. W pobliżu grobu nr 126 natrafiono na pochówek z obstawą kamienną (grób nr 93), wyposażony w patenę, kielich, pierścień z karneolem oraz krzywaśń pastorału (Józefowiczówna 1963, s. 141, ryc. 35). Zachowały się również złote nitki z rozłożonego ornatu. Chronologię grobu określono na przełom XII i XIII wieku, choć kamienna obstawa skłania do jej przesunięcia na połowę XIII stulecia. Argumentem na zmianę datowania tego obiektu jest również kształt krzywaśni pastorału ze spłaszczonym nodusem, który nawiązuje do pastorału z grobu Boguchwała (także podobny poziom zalegania). Drugi pochówek z obstawą kamienną (nr 99) zarejestrowano w południowej części nawy głównej, na wysokości drugiego od zachodu filara romańskiego (Józefowiczówna 1963, s. 185). Zmarłego hierarchę wyposażono w pastorał $\mathrm{z}$ piórem wykonanym $\mathrm{w}$ technice emalii żłobkowej, który stanowi import warsztatów limuzyjskich z około połowy XIII wieku, przypuszczalnie z pracowni mistrza G. Alpais (Józefowiczówna 1957).

Szczególnie cenne wydają się wyniki badań przeprowadzonych w 2000 roku na placu Katedralnym przez Pracownię Archeologiczno-Konserwatorską kierowaną przez Henryka Klundera (Pawlak 2003; 2005). Na cmentarzysku odsłoniętym przed zachodnią fasadą katedry wydzielono 79 pochówków, zalegających w pięciu poziomach. Na najniższym udokumentowano pięć pochówków w sarkofagach, mających postać kamiennej obudowy (groby 10, 23, 69, 79, 80; ryc. 8). Materiał $\mathrm{z}$ jakiego wykonano tę obudowę - obrobione bloki martwicy wapiennej - odnajdujemy w bryle korpusu nawowego romańskiej katedry (Pawlak 2003, s. 46-53, 57). Wkopanie pochówków w warstwy wczesnośredniowieczne z końca XII i 1. połowy XIII wieku umożliwia datowanie powstania tej części cmentarza na 2. połowę XIII wieku. Zaobserwowano jej regularne rozplanowanie - sarkofagi zalegały przynajmniej w dwóch rzędach. Natomiast na osi katedry stwierdzono większą przestrzeń między grobami (groby 23 i 69), która wyznaczała aleję. Autor badań - Paweł Pawlak - łączy pochówki w sarkofagach z niższym klerem, choć nie wyklucza również możliwości chowania tu kanoników w związku z ograniczoną przestrzenią wewnątrz kościoła katedralnego. Pozostałe pochówki stanowią już drugą fazę użytkowania cmentarza, datowaną od XIV do początków XVIII wieku (Pawlak 2005, s. 62).

\section{Zakończenie}

Okres przebudowy katedry w połowie XIII wieku wpisuje się w intensywność przemian terytorialnych, własnościowych, kulturowych i społecznych na gruncie poznańskiej aglomeracji. Tak o sprowadzeniu obcych warsztatów do 
Poznania pisał Adam S. Labuda: „Ranga wykonawców wskazuje, że zamówienie to mogło wyniknąć jedynie $\mathrm{z}$ wiedzy i kontaktów wysoko postawionych fundatorów - chodzi o kler katedralny i zapewne też Przemysła I jako fundatora klasztoru dominikanów. [...] W sferze działalności zarysowują się dwa powiązane współpracą ogniwa: ośrodek władzy świeckiej [...] oraz ośrodek katedralny" (Labuda 2005, s. 264-265). Można sądzić, że zaangażowanie francuskich budowniczych do prac przy budowie nowego chóru przez biskupów poznańskich nie wynikało tylko z ich wykształcenia i kontaktów przejawiających się choćby obecnością przedmiotów luksusowych. Była też rodzajem manifestacji możności i władzy biskupiej. Katedra mimo, że znalazła się na uboczu nowo lokowanego miasta, nadal stanowiła jego centrum duchowe i religijne. Przebudowa obiektu w połowie XIII wieku uwarunkowana była tradycją i sacrum - miejsca narastania kolejnych budowli począwszy od niewielkiego budynku baptysterium, pierwszej przedromańskiej katedry i jej fazy romańskiej (Józefowiczówna 1963; Kurnatowska 1998). Na romańskim korpusie nawowym powstałym w 1. połowie XII wieku oparł się dostawiony wczesnogotycki chór. Oś romańskiej nawy głównej wytyczyła oś całej budowli i jej odchylenie na południowy wschód w stosunku do osi katedry gotyckiej zdaje się tłumaczyć odchylenie dawnej kaplicy mansjonarskiej (obecnej Złotej Kaplicy). Wydaje się, że takie spojrzenie może być kolejną przesłanką do obecności obejścia wokół chóru, a wschodnią kaplicę dostawiono bazując na tej osi (przed przebudową chóru z XIV/XV wieku). Tradycja romańskiego korpusu była tak silna, że w XIV-wiecznej przebudowie pozostawiono fragment ściany $\mathrm{z}$ ciosów w fasadzie zachodniej katedry.

Nowością natomiast było sprowadzenie budowniczych z Francji, dzięki temu katedra zyskała pierwsze na ziemiach polskich wieloboczne zamknięcie chóru. Francuskim kamieniarzom Poznań zawdzięcza dekoracyjne kapitele z piaskowca i być może obejście z dostawianymi później kaplicami. Wielobocznie zamknięty chór wczesnogotycki z połowy XIII wieku był nowatorskim rozwiązaniem, pierwszym takim na ziemiach polskich. Fakt sprowadzenia przez biskupa Boguchwała II (który według historyków mógł kończyć studia we Francji) francuskich budowniczych świadczy o jego wykształceniu oraz znajomości najistotniejszych trendów w architekturze sakralnej ówczesnej Europy. Związki z Francją potwierdza również obecność w jednym z grobów biskupich pastorału z Limoges, wysokiej klasy wytworu ówczesnej europejskiej sztuki złotniczej. Pośrednimi śladami przebudowy partii chóru w połowie XIII wieku są pochówki w obstawie z kamiennych ciosów i bloków martwicy. Materiał porozbiórkowy z romańskiego chóru wykorzystano wtórnie do budowy sarkofagów zarówno wewnątrz, jak i na nowo powstałym cmentarzu przed katedrą.

Na podstawie nielicznych źródeł i reliktów o katedrze wczesnogotyckiej powstało wiele publikacji. Niestety, w dużej mierze możliwości interpretacyjne archeologa ogranicza metodyka i wyniki badań wykopaliskowych, szczególnie 
w okresie milenijnym. Można mieć nadzieję, że ewentualne dalsze remonty, osuszanie ścian i fundamentów, zwłaszcza w nienaruszanych sondażami i wykopami kaplicach poddawane będą gruntownym badaniom archeologiczno-architektonicznym. Wolno przypuszczać, że zaistnieje możliwość dokonania istotnych weryfikacji niektórych ustaleń. Szersze perspektywy rekonstrukcji katedry w XIII wieku mogłoby dać pozyskanie kolejnych fragmentów kamieniarki z okolic katedry lub z innych miejsc Ostrowa Tumskiego, gdzie na pewno trafiał porozbiórkowy rumosz.

\section{Literatura}

Wykaz skrótów

KMP - Kronika Miasta Poznania, Poznań

Gałka W.

1990 Materiały z prac przy elewacjach otaczających prezbiterium katedry poznańskiej, Poznań, maszynopis w Biurze Miejskiego Konserwatora Zabytków w Poznaniu, Poznań.

2001 O architekturze i plastyce dawnego Poznania do końca epoki baroku, Poznań. Informator

1975 Poznań-Ostrów Tumski. Katedra, Informator Archeologiczny. Badania rok 1974, Warszawa, s. 192-193.

Jan z Czarnkowa

1996 Kronika Jana z Czarnkowa, thum. J. Żerbiłło, oprac. M. D. Kowalski, Kraków. Józefowiczówna K.

1957 Nieznany zabytek średniowiecznej emalii z katedry poznańskiej, Studia Muzealne, t. 2, s. 36-70.

1963 Z badań nad architektura przedromańska i romańska w Poznaniu, Wrocław. Kaczmarek J.

2008 Archeologia Miasta Poznania. Stan badań i materialy, t. 1, cz. 1, Poznań. Katalog

1983 Katalog zabytków. Miasto Poznań, cz. 1: Ostrów Tumski i Śródka z Komandoria, red. E. Linette, Z. Kurzawa, Warszawa.

Kóčka-Krenz H.

2000 Wczesnopiastowski Poznań w świetle źródet archeologicznych, [w:] Gniezno i Poznań w państwie pierwszych Piastów, red. A. Wójtowicz, Poznań, s. $61-76$.

Kowalski J.

2010 Gotyk Wielkopolski. Architektura sakralna XIII-XVI wieku, Poznań. 


\section{Kronika}

1965 Kronika Wielkopolska, tłum. K. Abgarowicz, oprac. B. Kürbisówna, Warszawa.

Krzyślak B., Kurzawa Z.

2011 Kościól św. Jana Jerozolimskiego za Murami na poznańskiej Komandorii, Poznań.

Kurnatowska Z.

1998 Poznańskie baptysterium, Slavia Antiqua, t. 39, s. 51-69.

Kusztelski A.

2003 Prezbiterium katedry poznańskiej. Rekonstrukcjafaz, układ, zwiazki i wpływy, KMP, z. 2003/1, s. 157-178.

Kutzner M.

1969 Sztuka gotycka. Architektura, [w:] Dzieje Wielkopolski, t. 1: Do roku 1793, red. J. Topolski, s. 372-396.

Labuda A. S.

2005 Dynamika życia artystycznego w średniowiecznym Poznaniu, [w:] Civitatas

Posnaniensis. Studia z dziejów średniowiecznego Poznania, red. Z. Kurnatowska, T. Jurek, Poznań, s. 263-274.

Linette E.

1953 Zabytek wczesnogotyckiego budownictwa w Poznaniu, Przegląd Zachodni, t. 9, z. 6-8, s. 466-479.

1959 Wczesnogotycki wystrój chóru kościoła dominikanów w Poznaniu, Biuletyn Historii Sztuki, t. 21, nr 3/4, s. 344-357.

1988 Ogotyckiej architekturze katedry poznańskiej, [w:] Podtug nieba i zwyczaju polskiego. Studia z historii architektury, sztuki i kultury ofiarowane Adamowi Miłobędzkiemu, Warszawa, s. 92-104.

Monumenta

1932 Monumenta Poloniae Historica, t. 2, Lwów.

Nowacki J.

1959 Dzieje Archidiecezji Poznańskiej, t. 1: Kościół Katedralny w Poznaniu. Studium historyczne, Poznań.

Pawlak P.

2003 Cmentarze przykatedralne, [w:] O. Antowska-Gorączniak, A. Sikorski, P. Pawlak, P. Wawrzyniak, Cmentarze Ostrowa Tumskiego, KMP, z. 2003/1, s. 40-57.

2005 Cmentarzyska przedlokacyjnego Poznania, [w:] Civitas Posnaniensis. Studia z dziejów średniowiecznego Poznania, red. Z. Kurnatowska, T. Jurek, Poznań, s. 59-109.

Przywileje

1994 Przywileje miasta Poznania XIII-XVIII wieku, wyd. W. Maisel, Poznań. Przewoźna K.

1959 Badania w katedrze poznańskiej w 1946 r., [w:] Poznań we wczesnym średniowieczu, t. 1, red. W. Hensel, s. 59-79. 


\section{Roczniki}

1995 Roczniki Wielkopolskie, tłum. A. Pawalczyk, współpraca J. Wiesiołowskiego, KMP, z. 1995/2, s. 67-122.

Skibiński S.

1995 Nagrobek Bolesława Chrobrego w katerze poznańskiej, KMP, z. 1995/2, s. $165-176$.

1996 Polskie katedry gotyckie, Poznań.

2001 Katedra poznańska, Poznań.

2003 Królewski charakter katedry poznańskiej, KMP, z. 2003/1, s. 126-156.

2004 Rzéba zworników chóru kościoła dominikańskiego, KMP, z. 2003/3, s. 85-94.

2005 Architektura kościołów średniowiecznego Poznania, [w:] Civitas Posnaniensis. Studia z dziejów średniowiecznego Poznania, red. Z. Kurnatowska, T. Jurek, Poznań, s. 245-262.

Świechowski Z.

1961 Wczesne budownictwo ceglane w Polsce, Studia z dziejów rzemiosła i przemysłu, t. 1, s. 83-124.

2000 Architektura romańska w Polsce, Warszawa.

Tomala J.

2007 Murowana architektura romańska i gotycka $w$ Polsce, t. 1: Architektura sakralna, Kalisz.

Sztuka polska

1971 Sztuka polska przedromańska i romańska do schyłku XIII w., [w:] Dzieje sztuki polskiej, t. 1, cz. 2, red. M. Walicki, Warszawa.

Zachwatowicz J.

1971 Architektura. Architektura późnoromańska w wieku XIII, [w:] Dzieje sztuki polskiej, t. 1, cz. 2: Sztuka polska przedromańska i romańska do schyłku XIII w., red. M. Walicki, Warszawa, s. 149-194.

Żywoty biskupów

2004 Żywoty biskupów poznańskich przez Jana Dlugosza kanonika krakowskiego napisane, [w:] Katalogi biskupów poznańskich, oprac. J. Wiesiołowski, Poznań, s. 4-37.

\section{THE EARLY GOTHIC CATHEDRAL IN POZNAŃ}

The article presents the main results of research and scientific discussion as well as many interpretations related to the reconstruction of the choir of Poznań Cathedral in the mid- $13^{\text {th }}$ century. It also details the subsequent construction work carried out before the Gothic reconstruction of the nave (mid-14 ${ }^{\text {th }}$ century). These works are clearly shown in the written sources, and they can be dated from 1243 to 1262 . They were initiated by the Poznań bishops, Boguchwał II and Boguchwał III (consecration of the choir - June 29, 1262). Basic, but unfortunately only fragmentary, early Gothic remains were unearthed by archaeological excavations conducted after World War II (1951-1956). Further obser- 
vations possibly concerning this construction phase were made on the occasion of the drying of the walls and foundations in 1988 and from 1999 to 2000. An archive search in the City Heritage Conservator's Office in Poznan and in the Archive of the Museum of Archaeology in Poznań did not produce any worthwhile evidence. Unfortunately, some descriptions in literature are not supported by photographic documentation or drawings (amongst others, the possible wall of the transept/south chapel, Wendish bonds in the eastern and southern wall of the chapel).

The early Gothic choir was probably built of brick and stone. Based on shape of the rear surface of a capital with oak leaves, it was discovered that it had a polygonal closure. The style of the cathedral's stone detail (and the Dominican church) was associated with a French builders' guild (S. Skibiński). Recent excavations in the Ostrów Tumski (Cathedral Island) area (1999-2011) provided another fragment of the early Gothic stonework with a leaf motif(Ostrów Tumski, site 9). A curve clearly visible at its edge rather suggests that it was part of a keystone or portal's archivolt.

The article also describes the sepulchral character of the cathedral including royal burials and graves of bishops and clergy associated with the cathedral. Despite the archaeological excavations, burials of rulers still remain the subject of discussion and scarce written sources. The only one definitely identified is the royal chapel of Przemysł II and his wife Ryksa on the western side of the southern aisle. Its remains consist of two brick engaged columns attached to Romanesque pillars and a pillar in Wendish bond. The time of its construction is disputable; about 1293 or as late as about the mid-14 th century - when a (symbolic?) burials' transfer took place in connection with the erection of Bolesław the Brave's tombstone in the nave of the cathedral (S. Skibiński). Attributes such as croziers, rings, patens and a chalice indicate bishops' burials. Due to their seal ring, one of the two Boguchawł bishops - founders of the early Gothic choir - was identified (grave No. 126). Indirect evidence of construction works carried out in the mid- $13^{\text {th }}$ century are the re-used ashlars and blocks of calcareous sinter flanking the graves of bishops in the cathedral interior (graves 93 and 99) and recorded in 2000 in front of the western façade (5 graves). This material comes from the demolition of the Romanesque choir.

Reconstruction of the edifice in the mid- $13^{\text {th }}$ century was determined by tradition and sacrum - a place of the construction of the following buildings, from an suspected small baptistery building, the first pre-Romanesque cathedral and the Romanesque phase. To the Romanesque main body, built in the first half of the $12^{\text {th }}$ century, the early Gothic choir was attached. The axis of the Romanesque nave determined the axis of the whole building, its deviation to the south-east in relation to the axis of the Gothic cathedral seems to explain the deviation of the former mansionary chapel (currently the Golden Chapel). This may also be evidence for the presence of the ambulatory around the choir, while the eastern chapel was an attached building based on this axis (before the reconstruction of the choir in the $14^{\text {th }} / 15^{\text {th }}$ century). Presumably the deviation to the south-east of the former mansionary chapel can be explained by its situation on the axis of the Romanesque nave and the early Gothic choir. In the mid- $14^{\text {th }}$ century, the axis of the nave was changed and deviated to the north. The early Gothic choir was demolished during the rebuilding of the cathedral in the late $14^{\text {th }}$ century.

A new feature during the construction work in the mid- $13^{\text {th }}$ century was the employment of French builders' guilds. Due to this the cathedral was the first one in Poland to have a polygonal closure for the choir. Poznań owes its decorative sandstone capitals and perhaps the ambulatory with later attached chapels to French stonemasons. Also the crozier from Limoges (from grave No. 99), a high-status product of European goldsmith's 
art from around the mid- $13^{\text {th }}$ century, is more evidence of the contacts of Poznan bishops with French areas.

The period of the cathedral rebuilding in the mid- $13^{\text {th }}$ century was part of intensive territorial, ownership, cultural and social changes taking place in the Poznań agglomeration. It seems that the involvement of French builders on the construction work of the new choir funded by Poznań bishops was not just due to their education but to contacts manifested by the presence of luxury items. The choir construction was a manifestation of episcopal wealth and authority. The cathedral, despite the fact that it was situated outside the newly incorporated city, remained its spiritual and religious centre. 